Journal of Bangladesh Academy of Sciences, Vol. 37, No. 2, 249-252, 2013

- Short communication

\title{
MYCOFLORA ASSOCIATED WITH THE LEAVES OF SENNA ALATA (L.) \\ ROXB.
}

\author{
SHAMIM SHAMSI*, PRANAMI CHOWDHURY ${ }^{1}$ AND NAJMUN NAHER ${ }^{2}$ \\ Department of Botany, University of Dhaka, Dhaka-1000, Bangladesh
}

\begin{abstract}
Fungi associated with leaves of Senna alata (L.) Roxb. (Cassia alata L.) and their pathogenic potentiality have been discussed. A total of 8 species of fungi belonging to 8 genera of Deuteromycetes were found to be associated with $S$. alata. The fungi were Acromoniella sp., Arthrinium saccharicola Stevenson, Aspergillus niger Van Tiegh, Cladosporium cladosporioides (Fresen.) de Vries, Colletotrichum gloeosporioides (Penz.) Sacc., Curvularia lunata (Wakker) Boedijn, Nigrospora sphaerica (Sacc.) Mason, Pestalotiopsis guepinii (Desm.) Stay and unidentified Hyphomycetes, $C$. gloeosporioides and $P$. guepinii were found to be pathogenic to $S$. alata.
\end{abstract}

Key words: Mycoflora, Associated leaves, Senna alata

Senna Alata (L.) RoxB. belongs to the family Ceasalpinaceae. It is an erect herb, 6 to 12 feet tall with compound leaves. Terminal inflorescence is a spike with beautiful cluster of golden yellow flower resembles yellow candlesticks - earning its common name candlestick or candle bush. The plant is native to the Amazon Rainforest. Due to its beauty, it has been cultivated around the world as an ornamental plant and has been naturalized in many tropical regions in the world. Cassia alata is one of the best medicinal plant against bacteria, fungus, virus and parasite. Also used as remedy of arthritis, insect bite, ring worm and eczema. The plant contains a group of chemicals anthraqunones and saponin. These chemicals are well known for their laxative effect. Saponin expels intestinal parasites. The leaves or sap contain a fungicide, chrysophanic acid. Because of its antifungal properties, it is a common ingredient in soaps, shampoos and lotions in the Phillipines. The extract of the plant showed antifungal properties against Sclerotium rolfsii causing Cocoyam cormel rot in storage (Eunice and Osuji 2008). Agbagua et al. (2003) reported crude extracts of $C$. alata decrease the rate of germination, and inhibited radical elongation in Celosia argentea $\mathrm{L}$.

${ }^{*}$ Corresponding author: <Prof.shamsi@gmail.com>.

${ }^{1}$ Department of Botany, Officer on special duty, Director of Secondary and Higher Education, Dhaka, Bangladesh.

2 Department of Botany, Life \& Earth Science Group, National University, Gazipur-1704, Bangladesh. 
Many works have been done on alkaloids of $C$. alata and association of fungi with this plant in other countries. Phomopsis cassia Da Camara has been implicated as the cause of wilt and dieback of $C$. alata in Tanzania and Venezuela. Foliar leaf spot caused by Cercospora canescense Ell. \& Mart was reported from Cuba. Phaeoisariopsis simulata was reported on the plant from Colombia, USA and Venezuela (Jillian 1990). Present study was undertaken (i) to isolate the fungi associated with the healthy and diseased leaves of the plant and (ii) to test the pathogenic potentiality of the associated fungi.
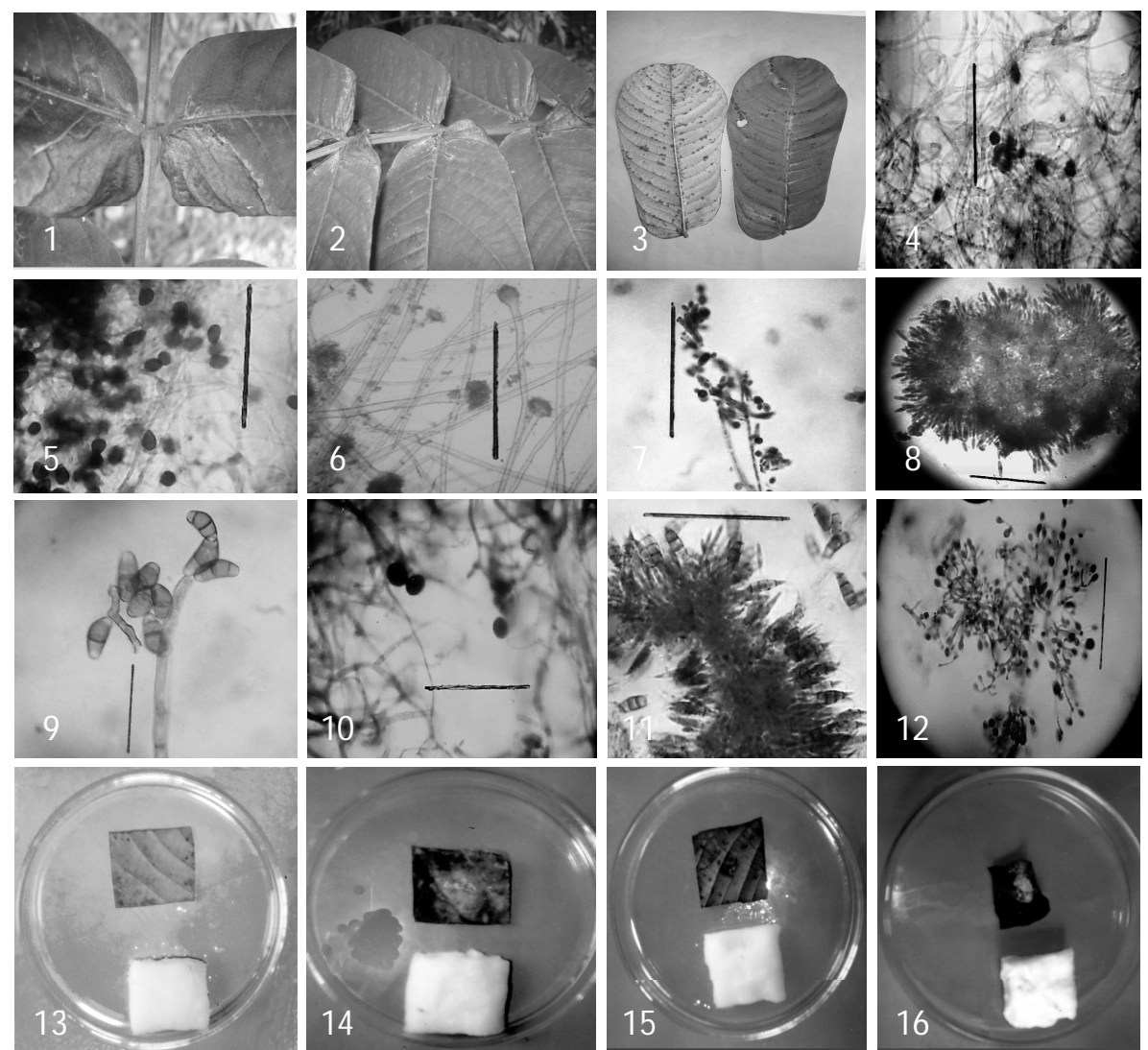

Figs. Anthracnose (1-2) and scattered, 3. Leaf spot of Cassia alata, 4. Acremoniella sp., 5. Arthrinium saccharicola, 6. Aspergillus niger, 7. Cladosporium cladosporioides, 8. Colletotrichum gloeosporiodes, 9. Curvularia lunata, 10. Negrospora sphaerica, 11. Pestalotiopsis guepinii, 12. Unidentified Hypomycetes, 13. Control, 14. Symptom produced by Colletotrichum gloesporioides, 15. Control, 16. Sympotom produced by Pestalotiopsis guepinii. $(\mathrm{Bar}=50 \mu \mathrm{m})$.

Healthy and infected leaf samples were collected from Savar, Gazipur and the Botanic Garden, University of Dhaka during the period of January, 2009 to December, 2010. Twenty five samples were examined from healthy and infected leaves of S. alata. The fungi were isolated on PDA (Potato Dextrose Agar) medium following "Tissue 
planting" method. The pathogenicity of the isolated fungi was tested following modified 'detached leaf technique (Azad and Shamsi 2011).

Identification of the isolates was determined following the standard literatures. (Ellis 1971, 1976, Sutton 1980). All the specimens were preserved in the Herbarium, Mycology and Plant Pathology division, Department of Botany, University of Dhaka, Bangladesh.

In Bangladesh research has been done on antifungal activities of $S$. alata but this is the first report of association of the fungi with S. alata (Rahman 2010). In the present investigation two types of symptoms were recorded on the plant i.e. anthracnose (Figs. 1-2) and indistinct small scattered leaf spots (Figs. 3). Healthy and infected leaves of $S$. alata were examined. Healthy leaves were completely free from fungal association.

Table 1. Frequency percentage of association of fungi with Senna alata.

\begin{tabular}{lccc}
\hline \multirow{2}{*}{ Fungal species } & Healthy leaves & \multicolumn{2}{c}{ Symptom type } \\
\cline { 3 - 4 } & & Anthracnose & Scattered spot \\
\hline Acromoniella sp. & - & - & 1.70 \\
Arthrinium sphaerica & - & - & 3.75 \\
Aspergillus niger & - & 10.00 & 20.00 \\
Cladosporium cladosporioides & - & 26.50 & 23.25 \\
Colletitrichum gloeosporioides & - & 53.00 & 24.75 \\
Curvularia lunata & - & - & 30.00 \\
Pestalotia guepinii & - & - & 35.00 \\
Nigrospora sphaerica & - & 16.50 & - \\
Unidentified Hyphomycetes & - & 2.00 & - \\
\hline
\end{tabular}

- = no isolate

A total of eight species of fungi belonging to eight genera of Deuteromycetes and one unidentified Hyphomycetes were found to be associated with S. alata. The fungi were Acromoniella sp., Arthrinium saccharicola Stevenson, Aspergillus niger van Tieghem, Cladosporium cladosporioides (Fresen.) de Vries, Colletotrichum gloeosporioides (Penz.) Sacc., Curvularia lunata (Wakker) Boedijn, Nigrospora sphaerica (Sacc.) Mason, Pestalotiopsis guepinii (Desm.) Stay and an unidentified Hyphomycetes. $C$. gloeosporioides and P. guepinii were found to be pathogenic to S. alata (Figs. 4-16).

Four fungal species were isolated from the leaves of $S$. alata showing anthracnose symptom. The isolated fungi were Aspergillus niger, Cladosporium cladosporioides, $C$. gloeosporioides, N. spaerica and an unidentified Hyphomycetes. Frequency of association of C. gloeosporioides was highest (53\%) and A. niger was lowest (10\%) (Table 1).

Five Colletotrichum species were recorded on Cassia spp. Colletotrichum capsici (Syd.) Butler \& Bisby has been recorded on C. occidentalis in Malaysia and C. tora in India. C. fragariae causes anthracnose of C. obtusifolia in Florida, C. gloeosporioides 
(Penz.) Sacc. has been recorded on C. absus in Zambia and C. alata in Tanzania and Venezuela. C. lindemuthianum (Sacc. \& Magn) Br. \& Cav has been found on C. fistula, C. occidentalis and C. tora in India; while C. truncatum (Schw.) Andrus \& Moore has been recorded on $C$. occidentalis in India and USA and $C$. rotandifolia in Colombia. $C$. truncatum has been considered as a biological control agent of the weed of coffee senna C. occidentalis in USA

The present report is the first one of the association of the fungi with $S$. alata in Bangladesh. At the same time except $C$. gloeosporioides this is the first record of association of these fungi with $S$. alata.

In case of infected leaves of $S$. alata with indistinct scattered spots, seven fungal species were isolated. The isolated fungi were A. atra, Arthrinium saccharicola, A. niger, Cladosporium cladosporioides, C. gloeosporioides, C. lunata, and P. guepinii. Frequency of association of P. guepinii was highest (35\%) and Acromoniella sp. was lowest (1.75\%), (Table 1).

All the fungi isolated from $S$. alata were tested for their pathogenic potentiality following "Detached leaf assay" technique. Among the fungi $C$. gloeosporioides and $P$. guepinii produced symptoms on dorsally and ventrally pricked inoculated leaf pieces. Unpricked and pricked uninoculated control leaf pieces did not produce symptom.

\section{REFERENCES}

Agbagwa, I.O, F.A . Onofeghara and S.I. Mensha. 2003. Stimilation of growth and development of Celosia argentica L. by crude extracts of Senna alata (L.) Roxb. J.l. Appl. Sci. Envoron. Mgt. 7(1): 9-13.

Azad, R. and S. Shamsi. 2011. Identification and pathogenic potentiality of fungi associated with Huttuyania cordata Thunb. Bangladesh J. Pl. Pathol. 20:(2):131-138.

Ellis, M.B. 1971. Dematiaceous Hyphomycetes. The Commonwealth Mycological Institute, England. pp. 608.

Ellis, M.B.1976. More Dematiaceous Hyphomycetes. The Commonwealth Mycological Institute, England, pp. 507.

Eunice O, N. and J.O. Osuji. 2008. Evaluation of plant extracts for Antifungal Activity Against Sclerotium rolfsii Causing Cocoyam Cormel Rot in Storage. Research Journal of Agriculture and Biological Sciences 4 (6):784 787.

Hirt, H. M. and B. Mpia. 2008. Natural Medicine in the Tropics 1: Foundation Text,. Germany. pp. 241.

Jillian, M.L. 1990. Diseases of Cassia species - a review. Tropica Grasslands 24:311- 324.

Rahman, M.A. 2010. Indigenous Knowledge of Herbal Medicine in Bangladesh. 3. Treatment of skin diseases by Tribal communities of the hill tracts Districts. Bangladesh J. Bot. 39(2): 169-177.

Sutton, B.C. 1980. The Coelomycetes. Fungi Imperfect with Pycnidia Acervuli and Stroma. Commonwealth Mycological Institute, Kew Surrey, England. pp. 696. 